ISSN 0975-3311

Ushus JBMgt, 9, 2 (2010) 81-92

ISSN 0975-3311 | https://doi.org/10.12725/ujbm.17.7

\title{
BALANCE SCORECARD -FINANCIAL PERSPECTIVE STUDY OF HINDUSTAN AERONAUTICS LIMITED
}

\author{
Leena James* \& Jeetendra Panigrahi**
}

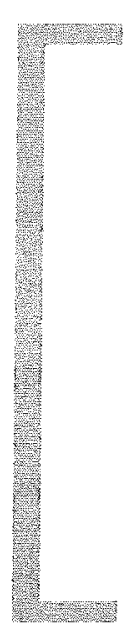

ABSTRACT

In the current globalized and highly competitive environment, maintaining long term competitiveness requires companies to engage in overall strategic planning and performance evaluation. The balanced scorecard is now a well-known and widely used management tool for balancing an organization's performance and can react to situations. Kaplan and Norton (1992) present the balanced scorecard as an alternative to the exclusive use of financial measures to manage company performance. This approach assists in strategy planning, process management, and performance evaluation from four perspectives, including financial, customer, internal process, and learning and growth. These four perspectives transform an organization's vision and strategy into a new performance evaluation system with objectives and measures. This study mainly focuses on

* Dept. of Management Studies, Christ University, Bangalore. Email: leena.james@christuniversity.in

** Ernst and Young, Global Shared Services, Bangalore, E-mai: jeetendrapanigrahi @gmail.com 
how a large aviation company Hindustan Aeronautics Limited, utilize balanced scorecard for its competitive advantage. As the technical perspective is important in the aviation 'industry besides the above four perspectives, this company has added the technical perspective also for the scorecard.

Keywords: Balanced scorecard, Financial Perspective, Hindustan Aeronautics Limited

\section{Introduction}

Kaplan and Norton (1992, 2000, 2001, 2004) present the balanced scorecard as an alternative to the exclusive use of financial measures to manage company performance. The balanced scorecard is now a wellknown and widely used management tool. Reportedly, over 60 percent of Fortune 1000 companies used balanced scorecard sysiems by 2001 (Bourne 2002), and over 72 percent of firms surveyed by Bain \& Company used them by 2004 .

The balanced scorecard retains traditional financial measures to indicate profitability, growth, and shareholder value, but also includes the nonfinancial measures that drive the financial results. Managers typically use the balanced scorecard to look at their business from four perspectives: the learning and growth perspective, internal business perspective, customer perspective, and the financial perspectives. A balanced scorecard system consists of objectives and corresponding performance measures for each of the four perspectives. The objectives and measures are linked together so that short-term actions support long-term strategic objectives (e.g., Kaplan and Norton 1996a).

\section{Origin}

The balanced scorecard concept dates back to 1988, when KPMG designed a performance evaluation system for APPLE. Later, in 1990, the Nolan Norton Institute sponsored a research project entitled "evaluation of future organization performance", led by Professor Robert Kaplan of Harvard University as a representative of academia and the CEO of Nolan ,David Norton as a representative of industry to evaluate the performance of 12 companies. The project was completed in December 1990 and published in the Harvard Business Review. Norton and Kaplan mentioned the concept 
of the balanced scorecard, which applies an overall management system to help managers acquire complete information very quickly, and learn the status of their business. The balanced scorecard is a total man-agreement system for translating strategy into action, and its core value is achieving the company vision and strategy. The key objective is to transform company strategy into action to improve competitiveness.

The four perspectives include the traditional financial indicators and add three non-financial operating indicators, namely the customer perspective, the internal process perspective, and the learning and growth perspective. These four perspectives transform an organization's vision and strategy into a new performance evaluation system with objectives and measures. In practice, many companies using the balanced scorecard consider it an important management process, being used for individual and team objectives, as well as strategy feedback and learning. Consequently, the balanced scorecard has been promptly developed as a strategic management system.

\section{Four Strategic Perspectives}

The Balanced Scorecard concept involves creating a set of measurements for four strategic perspectives. These perspectives include: 1) financial, 2) customer, 3) internal business process and 4) learning and growth. The

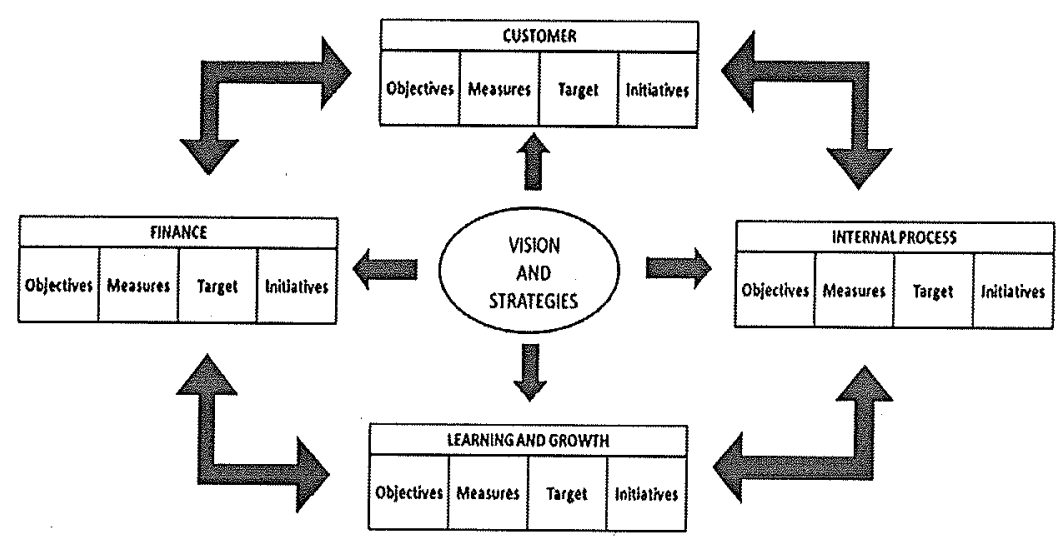

Figure 1. : Typical Perspectives on a Balanced Scorecard for the Public Sector 
idea is to develop between four and seven measurements for each perspective.

The graphic illustration below, help convey the idea.

The appropriate strategies and the action plans that are to be taken in the various activities should be decided so that it is clear as to how the organization has decided to pursue the pre-decided goals. Because of this reason, the balanced scorecard is often referred to as a blueprint of the company strategies.

\section{Literature Review}

Behrouz Aslani (2009) in his article 'Balanced Score Card- A survival path for Public Sector', stresses the importance in implementation of Balance score card in public sector organizations for achieving better results. According to him, the balanced scorecard methodology is founded on the ground of open line of communication among management and stakeholders.

Robert S Kaplan (2009) in his article "Lead and Manage" is of the opinion that for successful implementation of BSC the organizations need executives who can lead and manage.

Andra Gumbos and Bridget Lyons (2002) in their article The Balanced Score card at Philips Electronics, comment on how Philips Electronics have used the balanced scorecard to align company vision, focus employees on how they fit into the big picture, and educate them on what drives the business.

Douglas Scherer (2002) in his article 'Balanced Score Card overview', presents a general overview of the balanced Scorecard and links performance measures by looking at a firm's strategic vision from four different perspectives; Financial, Customer, Innovation \& learning \& internal businesses process.

Robert S Kaplan, David P Norton (1996) in their article linking the Balance Score Card to strategy, has proved that for successful implementation of the Balanced Scorecard all the four perspectives play an important role. However, they also say that the financial perspective recognizes aggregate financial measures such as operating income, Return 
on Investment, Return on Capital Employed, Economic value Added, etc provides clear, unambiguous and objective goals on which all organization participants can focus.

Many researchers have proved that Balanced Scorecard is helpful in public organizations. One such study conducted by John Griffiths (2003) speaks about how BSC is used in New Zealand Government departments as a tool to clarify the vision and provide a framework for what the organization was attempting to achieve, to reflect the unique characteristics of the organization and to bridge the gap between an organization's strategy and the annual work program.

Lanen (1999) have examined the extent to which a broadest of organizational performance measures are used and whether these measures represent internal and external perspectives as well as financial and quantitative perspectives.

Joshi(2001) has examined the management accounting practices in a sample of sixty large and medium-sized manufacturing companies in India and compared the results with the study of Chenhall and Smith.

\section{Objectives}

- To identify the key performance indicators in financial Perspectives of Hindustan Aeronautics Limited.

- To study the financial perspective of the organization using balance score Card for the .

Measures: The study is based on the financial records of 3 years i.e. from 2006 to 2009 and some financial highlights in brief of the preceding years. Leading organizations are now finding new financial measures, as well as the non-financial measures. Rather than simply considering the obvious financial measures of revenue, profit, share value or dividend cover in the present study consideration is being given to a recently developed measure: Economic Value Added. This expresses the amount of value added by the efforts of each department in the organization and how those efforts help the overall financial objectives of the organization.

Data Collection Methods: Structured and unstructured interview with senior managers and chief financial officer of the organization (RWR\&DC). 
Secondary data was collected from financial journals and website of the company.

Statistical Tools Used: Time series analysis (method of least square) and economic value added were the tools used for the study. Economic Value Added: EVA measures whether the operating profit is enough compared to the total costs of capital employed. Stewart defined EVA (1990, p.137) as Net operating profit after taxes (NOPAT) subtracted with a capital charge.

\section{Findings}

TABLE 1.1 Calculation of Sales Forecast for 3 years using Time Series Analysis (Method of Least squares)

\begin{tabular}{|l|c|c|c|c|}
\hline Year $(X)$ & Sales $(Y)$ & $X Y$ & $X^{\wedge} 2$ & $Y c$ \\
\hline $2006-07$ & 7783.61 & 0 & 0 & 7632.64 \\
$2007-08$ & 8625.33 & 8625.33 & 1 & 8927.44 \\
$2008-09$ & 10373.38 & 20746.6 & 4 & 10222.24 \\
\hline$\Sigma X=3$ & $\Sigma Y=26782.32$ & $\Sigma X Y=29371.93$ & $\Sigma X^{\wedge} 2=5$ & \\
\hline
\end{tabular}

The straight line to be fitted to the data: $Y=a+b X$

Using the following equations; $\Sigma Y=\mathrm{Na}+\mathrm{b} \Sigma \mathrm{X}$

$$
\Sigma X Y=a \Sigma X+b \Sigma X \wedge 2
$$

$a=7632.64$ and $b=1294.80$

Thus, $Y_{c} 3=11517, Y_{c 4}=12,811$ and $Y_{c 5}=14,106$

TABLE 1.2 Forecasted sales (in Cr)

\begin{tabular}{|l|c|c|c|c|}
\hline Particulars & $2008-2009$ & $2009-2010$ & $2010-2011$ & $2011-12$ \\
\hline $\begin{array}{l}\text { Forecasted Sales } \\
\text { (using Time Series } \\
\text { Analysis) }\end{array}$ & 10222 & 11517 & 12811 & 14106 \\
\hline
\end{tabular}


The findings indicates that the company can expect to achieve a sales turnover of Rs. $11517 \mathrm{cr}$. in the year 2009-2010. It can further expect to achieve a turnover of Rs. 12811 and Rs. 14106 cr. in the year 2010 and 2011 respectively.

TABLE 1.3 Calculation of Sales Export Forecast for 3 years using Time Series Analysis (Method of Least squares)

\begin{tabular}{|l|c|c|c|c|}
\hline Year $(X)$ & Sales-Export $(Y)$ & $X Y$ & $X^{\wedge} 2$ & $Y c$ \\
\hline 0 & 270.51 & 0 & 0 & 266.35 \\
1 & 341.09 & 341.09 & 1 & 349.38 \\
2 & 436.58 & 873.16 & 4 & 432.39 \\
$\Sigma X=3$ & $\Sigma Y=1048.18$ & $\Sigma X Y=1214.25$ & $\Sigma X^{\wedge} 2=5$ & \\
\hline
\end{tabular}

The straight line to be fitted to the data: $Y=a+b X$

Using the following equations;

$$
\begin{aligned}
& \Sigma Y=N a+b \Sigma X \\
& \Sigma X Y=a \Sigma X+b \Sigma X^{\wedge} 2
\end{aligned}
$$

$a=266.35$ and $b=83.03$

Thus, $Y_{c} 3=515.44, Y_{c 4}=598.47$ and $Y_{c 5}$

TABLE 1.4 Forecasted export sales (in cr.)

\begin{tabular}{|l|c|c|c|}
\hline Particulars & $2009-2010$ & $2010-2011$ & $2011-12$ \\
\hline $\begin{array}{l}\text { Forecasted export Sales } \\
\text { (using Time Series Analysis) }\end{array}$ & 515.44 & 598.47 & 681.5 \\
\hline
\end{tabular}

The company has great potential in terms of Exports. The company can expect to achieve Rs.681.50 cr. by the end of 2011-12 through exports.

- The table above reveals that the firms' revenue expectations from foreign exports can be extremely positive over the coming years.

- This positive target demands great cooperation from all the departments in the organization for its achievement. Thus, the implementation of a Balance Score Card would help in tapping this potential by setting objectives and initiatives for each department. 
TABLE 1.5 Value Added Forecast for using Time Series Analysis (Method of Least squares)

\begin{tabular}{|l|c|c|c|c|}
\hline Year $(X)$ & Value Added $(Y)$ & $X Y$ & $X^{\wedge} 2$ & $Y_{c}$ \\
\hline $2006-07$ & 3221.48 & 0 & 0 & 3357.78 \\
$2007-08$ & 4107.09 & 4107.09 & 1 & 3834.49 \\
$2008-09$ & 4174.90 & 8349.8 & 4 & 4311.20 \\
\hline$\Sigma X=3$ & $\Sigma Y=11503.47$ & $\Sigma X Y=12456.89$ & $\Sigma X^{\wedge} 2=5$ & \\
\hline
\end{tabular}

The straight line to be fitted to the data: $Y=a+b X$

Using the following equations;

$$
\begin{aligned}
& \Sigma Y=N a+b \Sigma X \\
& \Sigma X Y=a \Sigma X+b \Sigma X^{\wedge} 2
\end{aligned}
$$

$a=3357.7$ and $\dot{b}=476.71$

Thus, $Y_{c 3}=4787.91, Y_{C 4}=5264.62$ and $Y_{c 5}=5741.33$

TABLE 1.6 Forecasted value added (in cr.)

\begin{tabular}{|l|c|c|c|c|}
\hline Particulars & $2008-2009$ & $2009-2010$ & $2010-2011$ & $2011-12$ \\
\hline $\begin{array}{l}\text { Forecasted Value } \\
\text { Added (using TSA) }\end{array}$ & 4311.20 & 4787.91 & 5264.62 & 5741.33 \\
\hline
\end{tabular}

Economic Value Added (EVA) $=$ NOPAT - Capital ${ }^{*}$ Cost Of Capital

$$
\begin{aligned}
& =1463.70-\left(5914.20^{*} 0.1097\right) \\
& =971.68 \mathrm{cr} .
\end{aligned}
$$

Economic value lost in the year 2008-09 $=(347.53)$

Economic value addition for the year 2007-08 $=971.66$ 
TABLE 1.7 Financial Perspective of Balanced Score Card

\begin{tabular}{|c|c|c|c|}
\hline Objectives & Measures & Targets & Initiatives \\
\hline $\begin{array}{l}\text { Increase } \\
\text { Revenue } \\
\text { Growth }\end{array}$ & $\begin{array}{l}\text { Sales: } \\
\text { Inland } \\
\text { Export }\end{array}$ & $\begin{array}{l}\text { 2008-09: } \\
10222 \text { cores* } \\
2009-10: \\
11517^{*} \\
\text { Export: } 2009-10 \\
515.44 \text { cores }^{* *}\end{array}$ & $\begin{array}{l}\text { Expand Products Offerings: } \\
\text { - Started producing (LCA) Tejas and } \\
\text { HAWK aircrafts due to a demand for } \\
\text { the aircraft. } \\
\text { - Realization of first flight of Light } \\
\text { Combat Helicopter (LCH). } \\
\text { - Production of Advanced Light } \\
\text { Helicopter (ALH) with emphasis on } \\
\text { developing an export market for it. } \\
\text { - Phase-3 and Phase-4 production of } \\
\text { Sukhoi-3OMki } \\
\text { To provide a better Credit Policy } \\
\text { keeping in mind the Working Capital } \\
\text { requirements of the firm. } \\
\text { - Pricing Dhruv higher than the current } \\
\text { price but lower than the competitor's } \\
\text { products. Eg: Bell Helicopters. } \\
\text { - Tie up with companies placed in } \\
\text { foreign companies to provide in- } \\
\text { country maintenance facilities. } \\
\text { - Obtain ISO certifications for the } \\
\text { products to increase Exports. } \\
\text { - Tovernance practices. } \\
\text { - Trogress in Design and Development } \\
\text { projects. Eg: LCH and LCA-Mk } \\
\text { - The com Mats. } \\
\text { the company at various air shows. } \\
\text { company with Rosoboron and UAC } \\
\text { Russia for co-development and co- } \\
\text { production of the Multirole Transport } \\
\text { Aircraft and the Fifth Generation } \\
\text { - }\end{array}$ \\
\hline
\end{tabular}




\begin{tabular}{|c|c|c|c|}
\hline Objectives & Measures & Targets & Initiatives \\
\hline $\begin{array}{l}\text { To increase } \\
\text { the } \\
\text { profitability } \\
\text { of the firm }\end{array}$ & \begin{tabular}{|l|} 
Return on \\
capital \\
employed. \\
(ROCE) \\
Net profit \\
ratio \\
Gross \\
profit ratio \\
\end{tabular} & $\begin{array}{l}\text { 2008-09: } \\
39.48 \% \\
2009-10 \\
\text { To stabilize the } \\
\text { Return on capital } \\
\text { employed. }\end{array}$ & $\begin{array}{l}\text { Reducing various non-operating } \\
\text { expenses to increase the net profit. }\end{array}$ \\
\hline $\begin{array}{l}\text { Cost } \\
\text { Reduction } \\
\text { and } \\
\text { optimization }\end{array}$ & \begin{tabular}{|l|} 
- Value \\
added \\
- Operating \\
ratio \\
- Cycle time \\
between \\
products \\
produced \\
and sold.
\end{tabular} & $\begin{array}{l}\text { Value added: } \\
2008-09- \\
4311.20^{* * *} \\
2009-10^{-} \\
4787.91^{* * *}\end{array}$ & $\begin{array}{l}\text { - Lean Management } \\
\text { - Enterprise Resource Planning (ERP) } \\
\text { - Outsourcing tasks not involving core } \\
\text { - competencies } \\
\text { - Reducing the carrying costs for raw } \\
\text { materials and finished goods by } \\
\text { reducing the production time cycle. } \\
\text { - The company introduced the concept } \\
\text { of Quality Circles }\end{array}$ \\
\hline $\begin{array}{l}\text { To increase } \\
\text { the } \\
\text { efficiency } \\
\text { in the } \\
\text { Working } \\
\text { Capital } \\
\text { Management }\end{array}$ & $\begin{array}{l}\text { Current } \\
\text { Ratio } \\
\text { Liquid Ratio } \\
\text { Stock } \\
\text { turnover } \\
\text { ratio } \\
\text { Debtors } \\
\text { turnover } \\
\text { ratio } \\
\end{array}$ & $\begin{array}{l}\text { To maintain the } \\
\text { standard ratio of } \\
2: 1 \\
\text { To maintain a } \\
\text { standard of } 1: 1\end{array}$ & $\begin{array}{l}\text { - To maintain an adequate amount of } \\
\text { raw material inventory. } \\
\text { - To pay off the current liabilities at a } \\
\text { faster rate. } \\
\text { - To sell finished goods as and when } \\
\text { they are produced and thereby avoid } \\
\text { excess finished goods inventory. }\end{array}$ \\
\hline $\begin{array}{l}\text { Risk } \\
\text { Manage- } \\
\text { ment }\end{array}$ & $\begin{array}{l}\text { Beta, } \\
\text { Standard } \\
\text { deviation }\end{array}$ & $\begin{array}{l}\text { Reduce business } \\
\text { risk. }\end{array}$ & $\begin{array}{l}\text { The company plans to evolve a policy } \\
\text { on risk management with a view to } \\
\text { develop risk strategy, risk identification } \\
\text { and risk control approaches to avoid, } \\
\text { reduce, share or accept business risks. }\end{array}$ \\
\hline $\begin{array}{l}\text { Increase } \\
\text { economic } \\
\text { profit }\end{array}$ & $\begin{array}{l}\text { Economic } \\
\text { Value } \\
\text { Added } \\
\text { (EVA) }\end{array}$ & $\begin{array}{l}\text { To have a } \\
\text { positive EVA in } \\
\text { the year } \\
2009-10\end{array}$ & \\
\hline
\end{tabular}

Source of data: Field study and the annual report of the company.

*Source Table 1.2, ** Source Table 1.4, ${ }^{* * *}$ Source Table 1. 